\title{
Integration of High- Temperature Gas-Cooled Reactors into Industrial Process Applications
}

October 2009
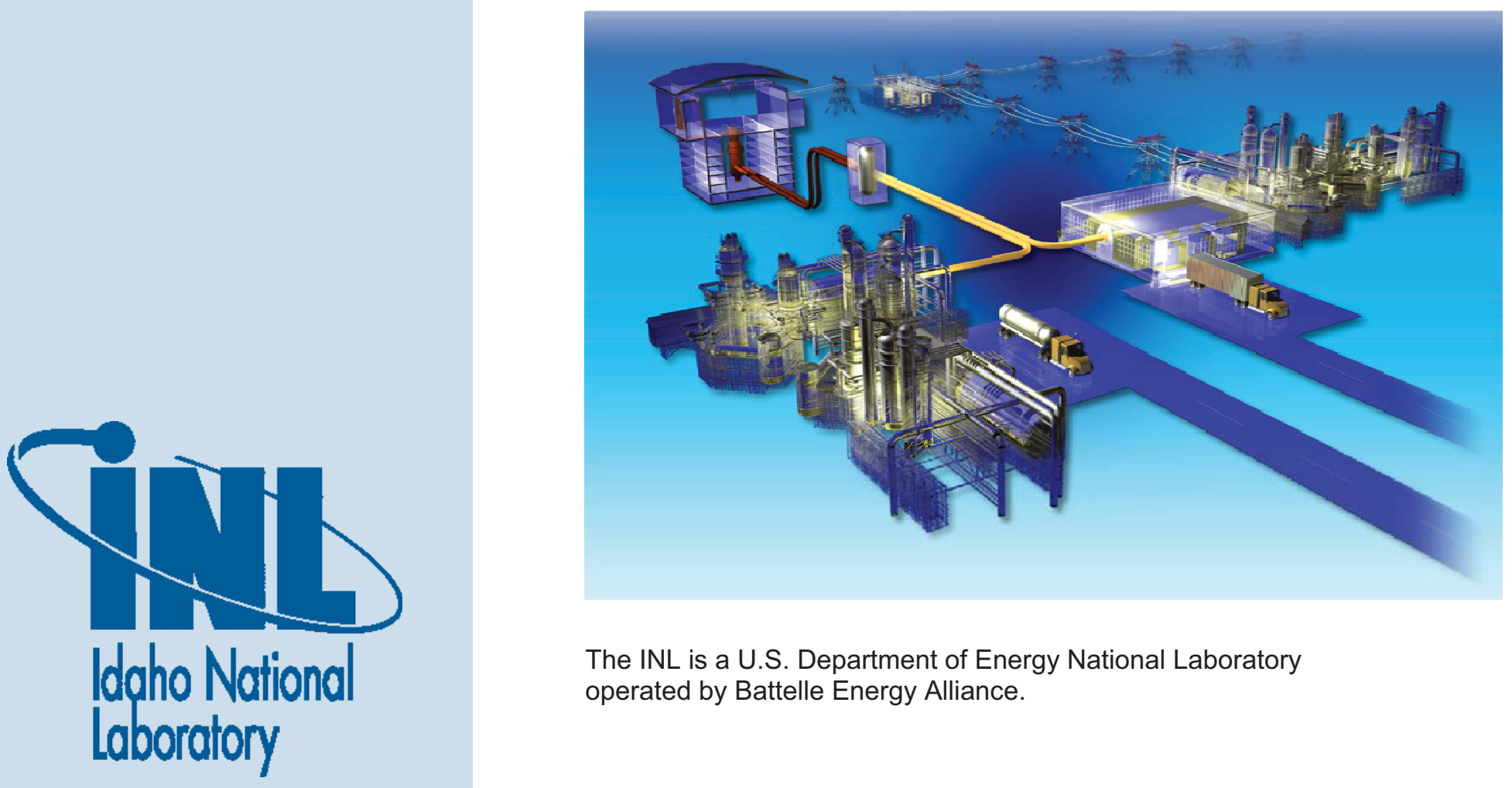

The INL is a U.S. Department of Energy National Laboratory operated by Battelle Energy Alliance. 


\section{DISCLAIMER}

This information was prepared as an account of work sponsored by an agency of the U.S. Government. Neither the U.S. Government nor any agency thereof, nor any of their employees, makes any warranty, expressed or implied, or assumes any legal liability or responsibility for the accuracy, completeness, or usefulness, of any information, apparatus, product, or process disclosed, or represents that its use would not infringe privately owned rights. References herein to any specific commercial product, process, or service by trade name, trade mark, manufacturer, or otherwise, does not necessarily constitute or imply its endorsement, recommendation, or favoring by the U.S. Government or any agency thereof. The views and opinions of authors expressed herein do not necessarily state or reflect those of the U.S. Government or any agency thereof. 


\section{Integration of High-Temperature Gas-Cooled Reactors into Industrial Process Applications}

October 2009

Idaho National Laboratory

Next Generation Nuclear Plant Project

Idaho Falls, Idaho 83415

Prepared for the

U.S. Department of Energy

Office of Nuclear Energy

Under DOE Idaho Operations Office

Contract DE-AC07-05ID14517 

Next Generation Nuclear Plant Project

\section{Integration of High-Temperature Gas-Cooled Reactors into Industrial Process Applications}

INL/EXT-09-16942

Revision 0

October 2009

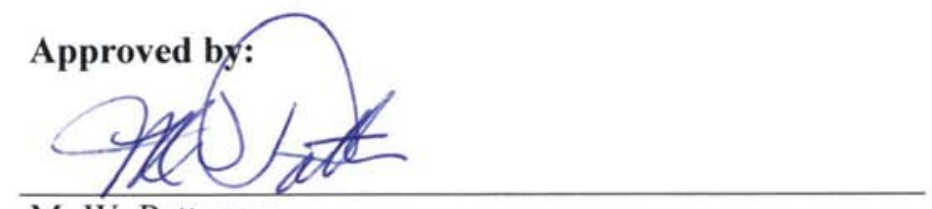

M. W. Patterson

Project Manager, Hydrogen and Heat Transport

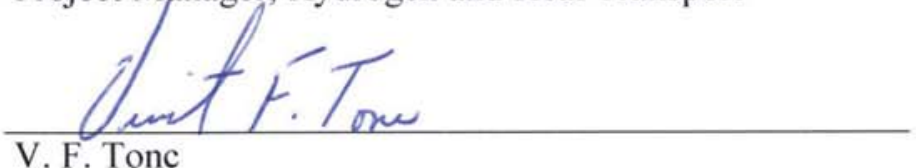

Manager, NGNP Engineering
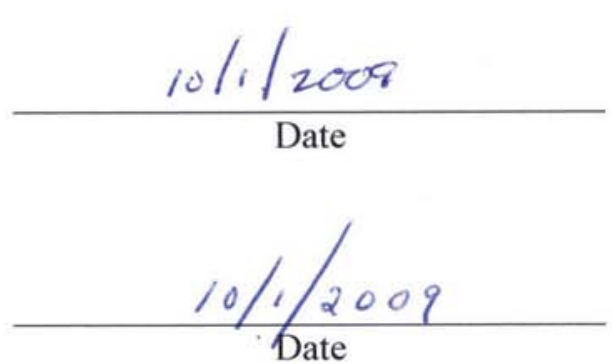



\section{EXECUTIVE SUMMARY}

As part of the Department of Energy's (DOE's) Idaho National Laboratory (INL) nuclear energy development mission, the INL contractor-Battelle Energy Alliance, LLC (BEA) - is leading a program to develop and design a high-temperature gas-cooled reactor (HTGR), which has been selected as the base design for the Next Generation Nuclear Plant (NGNP). Because an HTGR operates at a higher temperature, it can generate higher temperature steam and provide more usable process heat than a conventional light water reactor. Integrating HTGRs into conventional industrial processes would increase U.S. energy security and reduce greenhouse gas emissions, particularly carbon dioxide.

A two-phase study is underway to evaluate potential HTGR integration with conventional processes. During Phase 1, detailed mass and energy balances will be performed for conventional and nuclear-integrated processes. The Phase 1 results will include process inputs, heat requirements, products generated, and effluents. One of the major conclusions that may be drawn from the Phase 1 study is that nuclear-integrated processes would emit much lower quantities of carbon dioxide than conventional processes. See Figure 1 for a summary of the potential carbon dioxide emissions avoided through integration of nuclear heat with conventional processes.

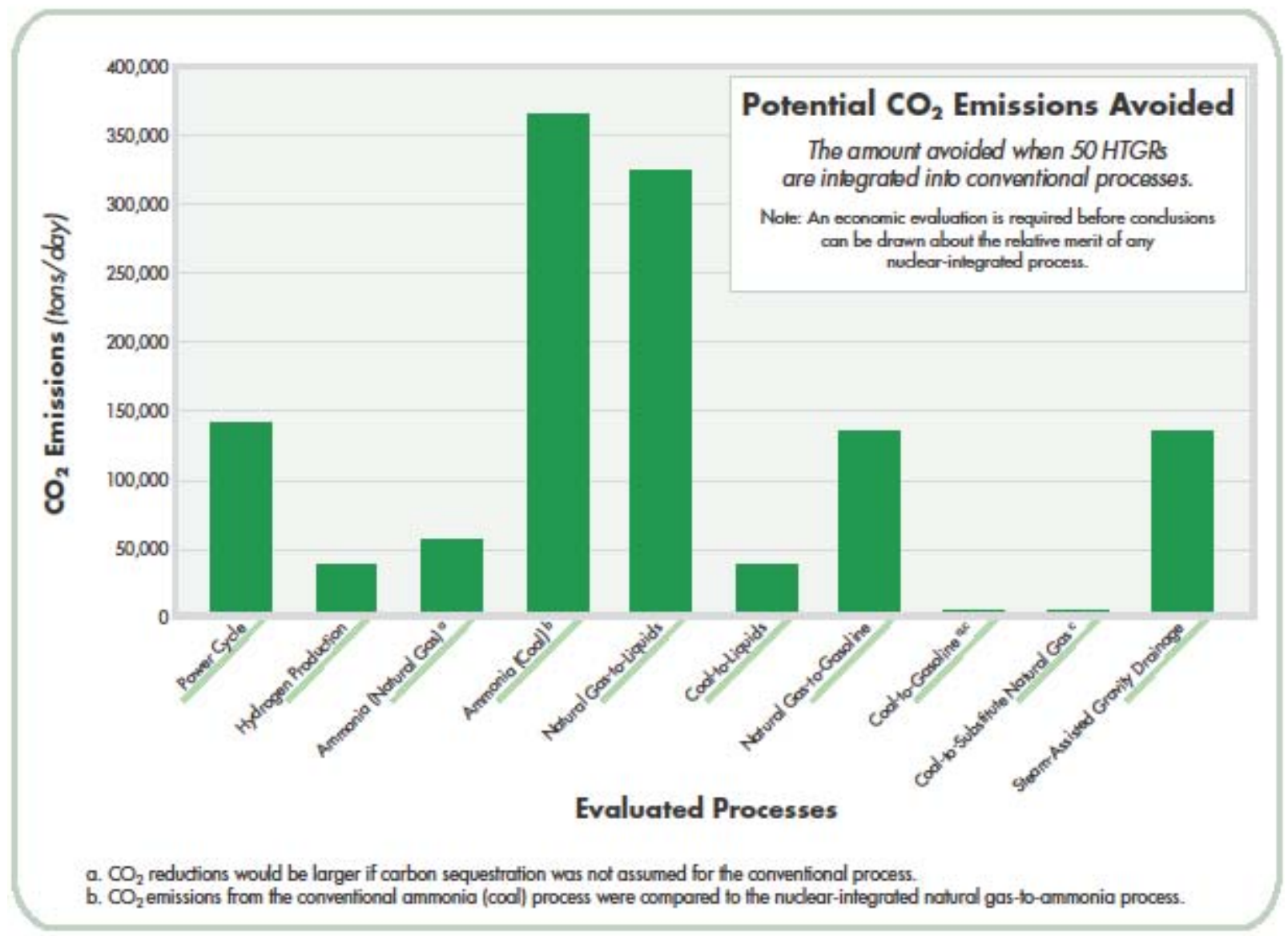

Figure 1 . The carbon dioxide emissions avoided by integrating fifty $600-\mathrm{MWth}$ hightemperature gas-cooled reactors (HTGRs) into conventional processes. 
This report summarizes the Phase 1 results. It provides a preliminary comparison of conventional and potential HTGR-integrated processes in several common industrial areas:

- Producing electricity via a conventional power cycle

- Producing hydrogen

- Producing ammonia and ammonia-derived products, such as fertilizer

- Producing gasoline and diesel from natural gas or coal

- Producing substitute natural gas from coal

- Extracting oil from Canadian oil sands (steam-assisted gravity drainage).

By integrating these processes, NGNP technology will offset imported fossil fuels, reduce greenhouse gas emissions and pollution, and create quality jobs in industries across the United States. Nuclear integration can potentially direct hundreds of billions of dollars currently spent on foreign fuel imports each year into the U.S. economy.

Phase 1 results are limited to relative carbon dioxide emissions from nuclear-integrated and conventional processes, and they provide insight into the impacts of constructing a fleet of HTGRs on the carbon footprint of industrial processes. As shown in Figure 1, the flow sheets evaluated in this report show promise for significantly decreasing carbon dioxide emissions associated with conventional processes. During Phase 2, a detailed economic analysis will be performed and will provide the basis for estimating the costs of conventional and nuclear-integrated processes. Based on the results obtained during this study, it is recommended that Phase 2 of the work be completed to enable more informed decisions about processes that may be suitable for nuclear integration. 


\section{CONTENTS}

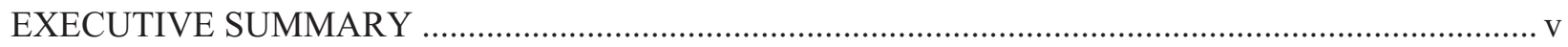

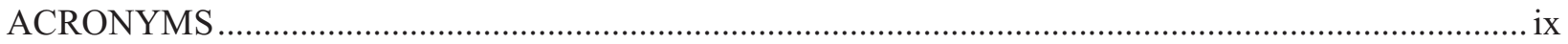

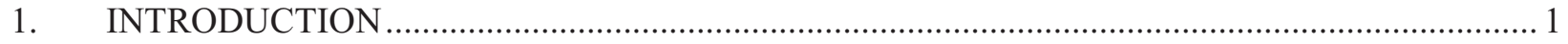

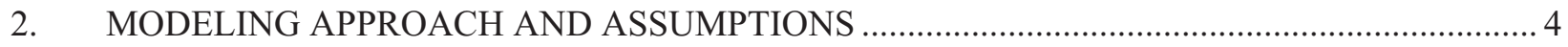

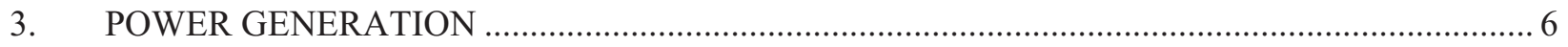

3.1 Power Generation — Cases Evaluated .......................................................................... 7

3.2 Power Generation — Preliminary Evaluation..................................................................... 7

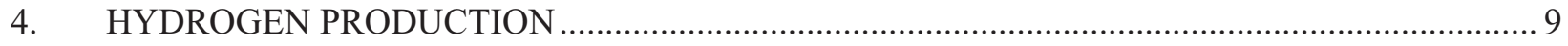

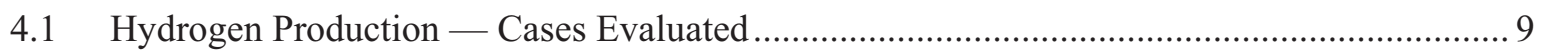

4.2 Hydrogen Production — Preliminary Evaluation ............................................................... 11

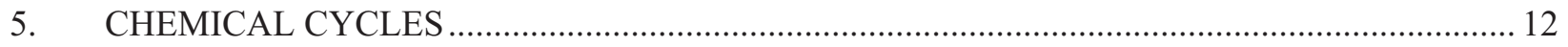

5.1 Ammonia and Ammonia-Derived Products ................................................................. 12

5.1.1 Ammonia Production — Cases Evaluated ................................................................ 13

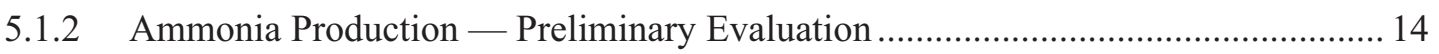

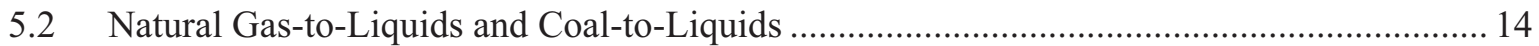

5.2.1 Natural Gas-to-Liquids and Coal-to-Liquids — Cases Evaluated ............................. 15

5.2.2 Natural Gas-to-Liquids or Coal-to-Liquids Production — Preliminary

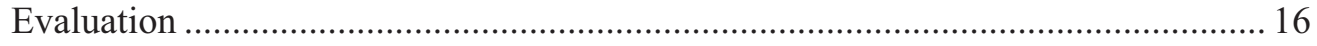

5.3 Natural Gas-to-Methanol-to-Gasoline and Coal-to-Methanol-to-Gasoline .......................... 16

5.3.1 Natural Gas-to-Methanol-to-Gasoline and Coal-to-Methanol-to-

Gasoline — Cases Evaluated ............................................................................. 18

5.3.2 Natural Gas-to-Methanol-to-Gasoline and Coal-to-Methanol-to-

Gasoline — Preliminary Evaluation ................................................................ 18

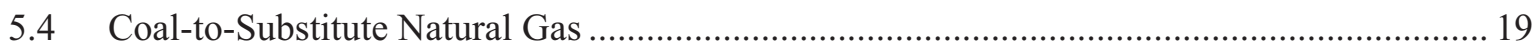

5.4.1 Coal-to-Substitute Natural Gas — Cases Evaluated ................................................ 19

5.4.2 Coal-to-Substitute Natural Gas — Preliminary Evaluation ....................................... 19

5.5 Steam-Assisted Gravity Drainage (Canadian Oil Sands).................................................. 20

5.5.1 Steam-Assisted Gravity Drainage (Canadian Oil Sands) — Cases

Evaluated....................................................................................................... 20

5.5.2 Steam-Assisted Gravity Drainage — Preliminary Evaluation .................................. 21

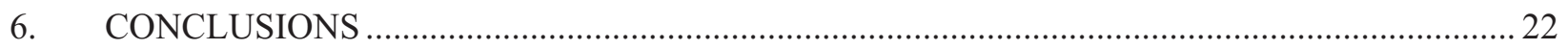

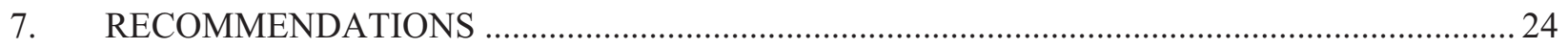

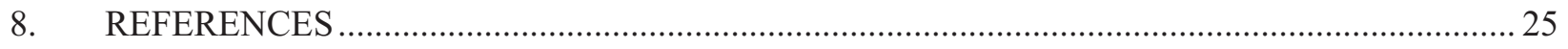




\section{FIGURES}

Figure 1. The carbon dioxide emissions avoided by integrating 50 high-temperature gascooled reactors (HTGRs) into conventional processes. V

Figure 2. A simplified flow sheet illustrates the carbon dioxide reductions that can be gained by using a nuclear-integrated gas-to-ammonia derivatives process instead of a conventional process. These cases, and others evaluated for the gas-toammonia derivatives process, are discussed in more detail on Page 12.

Figure 3. An illustration of the power generation cycles analyzed in this study shows that carbon dioxide reductions can be gained by using a nuclear-integrated process. The conventional case is shown as a basis for comparison.

Figure 4. A block diagram illustrates steam reforming using natural gas, a conventional technology for hydrogen production.

Figure 5. A block diagram illustrates hydrogen production using HTGR-assisted high-temperature steam electrolysis.

Figure 6. An illustration of the hydrogen production processes analyzed in this study shows that carbon dioxide reductions can be gained by using a nuclearintegrated process. The conventional case is shown as a basis for comparison

Figure 7. An illustration of the gas-to-ammonia derivatives processes analyzed in this study shows that carbon dioxide reductions can be gained by using a nuclearintegrated process. The conventional cases are shown as a basis for comparison.

Figure 8. An illustration of the coal-to-liquids and gas-to-liquids cases analyzed in this study shows that carbon dioxide reductions can be gained by using a nuclearintegrated process. The conventional cases are shown as a basis for comparison.

Figure 9. An illustration of the gas-to-methanol-to-gasoline and coal-to-methanol-togasoline cases analyzed in this study shows that carbon dioxide reductions can be gained by using a nuclear-integrated process. The conventional cases are shown as a basis for comparison.

Figure 10. An illustration of the coal-to-substitute natural gas cases analyzed in this study shows that carbon dioxide reductions can be gained by using a nuclearintegrated process. The conventional case is shown as a basis for comparison.

Figure 11. An illustration of the steam-assisted gravity drainage cases analyzed in this study shows that carbon dioxide reductions can be gained by using a nuclearintegrated process. The conventional case is shown as a basis for comparison.

\section{TABLES}

Table 1. Thermal efficiencies for the evaluated power generation cycles. 8

Table 2. The maximum possible reduction in carbon dioxide emissions for each industrial/chemical process. The results are based on a comparison of HTGRintegrated processes with conventional processes. The carbon dioxide emissions are not comparable. Some processes produce secondary products, such as excess electricity and oxygen. 


\section{ACRONYMS}

DOE Department of Energy

HTGR high-temperature gas-cooled reactor

HTSE high-temperature steam electrolysis

INL Idaho National Laboratory

LPG liquefied petroleum gas

MMSCFD million standard cubic feet per day

MTG methanol to gasoline

MWth megawatts thermal

MWe megawatts electrical

NGCC natural gas combined cycle

NGNP Next Generation Nuclear Plant

WBSCD World Business Council for Sustainable Development 


\section{Integration of High-Temperature Gas-Cooled Reactors into}

\section{INTRODUCTION}

At the December 2008 United Nations Climate Change Conference, representatives from the International Chamber of Commerce, the World Business Council for Sustainable Development (WBSCD), and other industrial groups advocated that nuclear power must be included in future climate change agreements. ${ }^{1}$ The WBSCD released a report calling for reducing emissions using a three-point strategy that includes "...progressive de-carbonization of the electricity mix, more efficient use of electricity, and enhanced substitution of electricity for fossil fuels." Under the report's scenarios, nuclear power could provide $14-15 \%$ of the emissions savings required. The report also called for including nuclear as an option in the Clean Development Mechanism included in the Kyoto Protocol.

Nuclear power is an essential component of a strategy to sharply reduce greenhouse gas emissions and can play an important role in displacing petroleum. Nuclear energy's capabilities for providing electricity are well known - approximately $20 \%$ of our needs in the United States, approximately $80 \%$ of carbon-free electricity, and more than $30 \%$ of the electricity generated worldwide. However, its capabilities for supplying heat for the chemical process industry are as yet not fully explored, in part because a new type of nuclear plant is required. Many conventional processes use heat generated by burning fossil fuels and in turn produce carbon dioxide emissions.

The U.S. Department of Energy (DOE) is currently funding research and development of a new reactor that is capable of providing high-temperature process heat for industry: a high-temperature gas-cooled reactor (HTGR). The HTGR operates at higher temperatures than reactors currently operating in the United States. Reactors that operate at higher temperatures can generate higher temperature steam and other high-temperature process heat that can be integrated into conventional industrial processes.

To evaluate potential applications for process heat, the Next Generation Nuclear Plant (NGNP) project commissioned a study to evaluate the economics of HTGR-integrated industrial/chemical processes as compared to those of analogous conventional processes. This report summarizes the first phase, which evaluated material and energy balances of conventional and HTGR-integrated processes in six common industrial/chemical areas.

The study shows that HTGR-integrated processes offer many advantages besides greater energy security. In general, all of the nuclear-integrated processes that were studied emitted significantly less carbon dioxide than the analogous conventional processes. The gas-to-ammonia derivatives case is a clear and striking example of the potential that HTGR-integrated processes hold for reducing greenhouse gas emissions, particularly carbon dioxide. As shown in Figure 2, a single 600-MWth HTGR-integrated process uses less natural gas and produces significantly less carbon dioxide emissions than a conventional process - 117 tons of carbon dioxide per day versus 1,283 tons per day. The figure illustrates an assumption that a portion of the concentrated carbon dioxide process streams are compressed and captured rather than being emitted. It is important to note that if all carbon dioxide produced in the ammonia process was emitted, the emissions would be 3,236 tons per day and 2,070 tons per day respectively for the conventional and nuclear-integrated processes. 


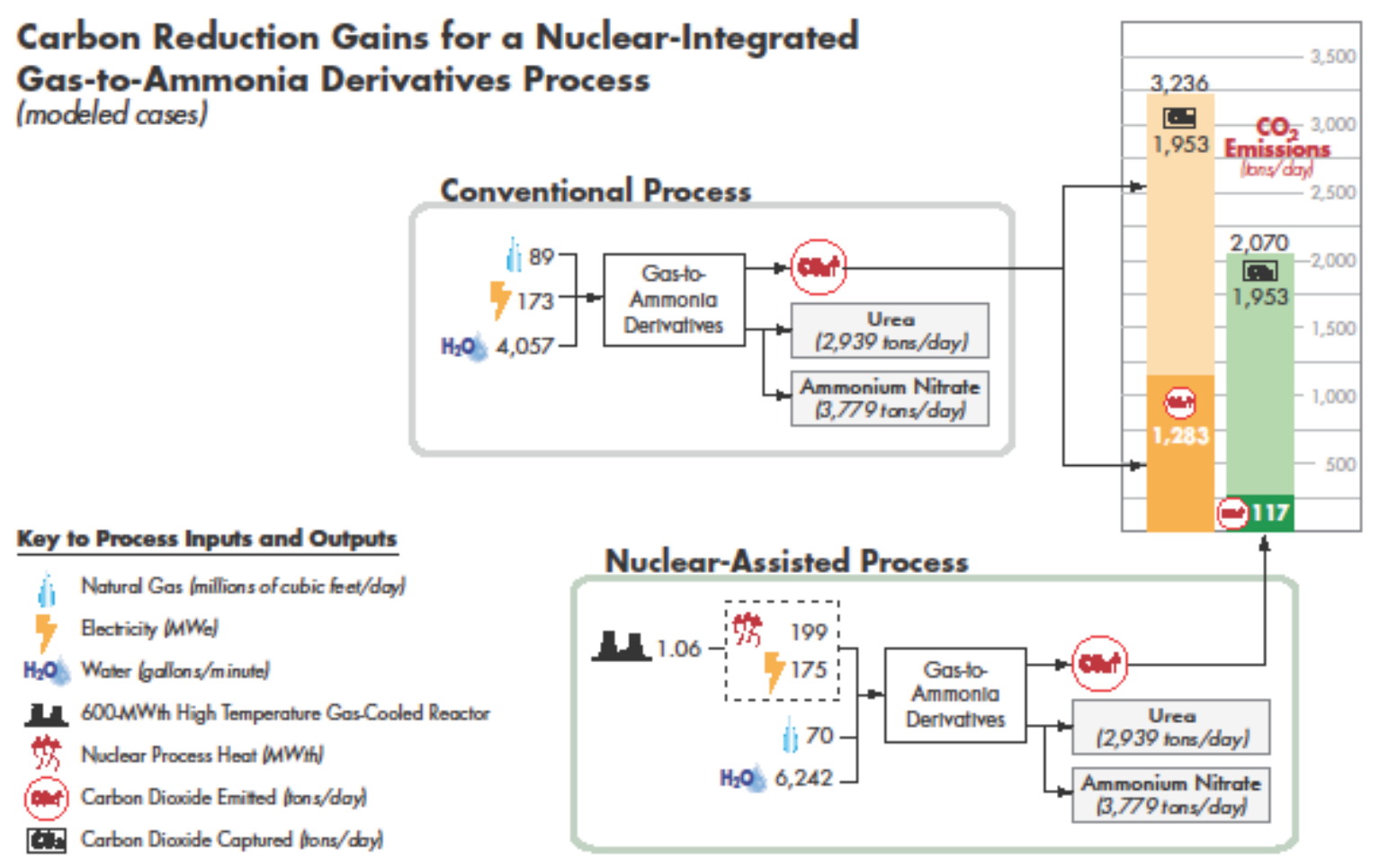

Figure 2. A simplified flow sheet illustrates the carbon dioxide reductions that can be gained by using a nuclear-integrated gas-to-ammonia derivatives process instead of a conventional process. These cases, and others evaluated for the gas-to-ammonia derivatives process, are discussed in more detail on Page 12.

If and when they are eventually implemented, nuclear-integrated industrial processes will increase their operating efficiency and uptime, just as the U.S. nuclear power program has accomplished so significantly. In clear contradiction of the now infamous quote in Forbes, "The failure of the U.S. nuclear power program ranks as the largest managerial disaster in business history", the industry has significantly increased its operating efficiency over the last 20 years. ${ }^{3}$ In 1980, the industry's capacity factor (output proportion of their nominal full-power capacity) was $56.3 \%$, but it improved to $66 \%$ by 1990 and to $91.1 \%$ by 2008 . One reason for the steady improvement was a progressive decrease in the duration of refueling outages, which averaged 107 days in 1990, dropped to 40 days by 2000, and continues to decrease. The record today is just 15 days. Another reason is that average thermal efficiency has increased, from $32.49 \%$ in 1980 , to $33.40 \%$ in 1990 , to $33.85 \%$ in 1999 . As a result of these and other improvements, output increased from 577 billion kWh in 1990 to 809 billion $\mathrm{kWh}$ in 2008, a 40\% increase that is equivalent to adding 29 new 1,000-MWe reactors. This significant improvement in operating efficiency was achieved with little increase in installed capacity. A similar expectation can be made for HTGR-integrated power generation. Ongoing improvements in HTGR-power plant utilizationimproved refueling, maintenance, and safety systems, and efficiencies gained from operating experience - will continue to reduce costs and extend the lifetime of plant components.

This report provides results from the first phase of a study to evaluate HTGR integration with conventional industrial processes. The results are limited to relative carbon dioxide emissions from nuclear-integrated and conventional processes, but they provide insight into the impacts of constructing a fleet of HTGRs on the carbon footprint of industrial processes. A detailed economic analysis will be performed in the next phase to provide a better understanding of the relative costs of a nuclear-integrated process as compared to a conventional process. 
This evaluation includes the following processes:

- Producing electricity via a conventional power cycle

- Producing hydrogen

- Producing ammonia and ammonia-derived products, such as fertilizer

- Producing gasoline and diesel from natural gas and coal

- Producing substitute natural gas from coal

- Extracting oil from Canadian oil sands.

This report is organized to facilitate a review of the preliminary results. Section 2 includes a brief summary of the modeling approach and the overall assumptions. Section 3 addresses power cycle generation. Section 0 addresses hydrogen production. Section 5 addresses the chemical processes. The conclusions are presented in Section 6, which is followed by recommendations for future work in Section 7. 


\section{MODELING APPROACH AND ASSUMPTIONS}

Detailed process plant models were developed for each of the processes evaluated in this study. Existing process models were used when available. As a result, a standard modeling platform was not used. The models for power cycles and hydrogen production via high-temperature steam electrolysis were developed on HYSYS. The steam-assisted gravity drainage (SAGD) models were developed in an Excel spreadsheet. All other models were developed in Aspen Plus. A determination has not been made whether modeling will be moved to a common platform during the next phase.

For the evaluation, all cases were adjusted to produce a typical daily output from a conventional industrial process. For example, the size in the ammonia case was adjusted to produce the standard output of a conventional ammonia plant: 2,939 tons/day of urea and 3,779 tons/day of ammonium nitrate.

The following assumptions were used to complete the calculations described in this report:

1. HTGR(s) are located within 200 meters of the process application, except in the calculations involving oil extraction from Canadian oil sands.

2. HTGR(s) can produce electricity, heat, and/or hydrogen.

3. Process heat from HTGR(s) can be supplied at $700^{\circ} \mathrm{C}$, corresponding to a reactor gas outlet temperature of $750-800^{\circ} \mathrm{C}$. The reactor gas inlet temperature is $322^{\circ} \mathrm{C}$ for prismatic fuel and $280^{\circ} \mathrm{C}$ for pebble bed fuel.

4. Heat output from HTGR(s) is $600 \mathrm{MWth}$. (Excess heat [if any] may be used for electrical generation or sale on the open market.)

5. Plant capacity is set using standard sizes and established chemical/fuel plant technologies. The heat, power, and hydrogen needed for the process establishes the number of HTGRs that are required.

6. For chemical/fuel plant technologies that are not yet fully established, a reasonable size is selected that corresponds with a whole number of HTGR(s).

7. HTGR power generation efficiency is $40 \%$ for all cases, with the exception of power generation, hydrogen production, and steam-assisted gravity drainage. (Note: The power systems studies show over $45 \%$ efficiencies may be attainable with regard to the combined cycle configurations arising from this study.)

8. Of the two potential hydrogen sources, high-temperature electrolysis (HTSE) and hybrid HTSE/thermochemical, only HTSE is considered.

9. Heat is provided to nuclear-integrated processes via steam except as noted.

10. All process heat exchanger calculations use a $10^{\circ} \mathrm{C}$ minimum temperature approach, except in specific cases based on demonstrated industrial experience when a larger minimum temperature approach is used.

11. All intermediate heat exchanger calculations use a $15^{\circ} \mathrm{C}$ minimum temperature approach.

12. The lower temperature limit achievable when using water or air for heat exchange is $40^{\circ} \mathrm{C}$. (When lower temperatures are required, a chiller or refrigeration is added to the flow sheet.)

13. The ambient inlet water temperature is $15.56^{\circ} \mathrm{C}\left(60^{\circ} \mathrm{F}\right)$.

14. For natural gas standard volume flow calculations, a temperature of $15.56^{\circ} \mathrm{C}\left(60^{\circ} \mathrm{F}\right)$ and pressure of 1 atmosphere are assumed.

15. The ambient inlet air temperature is $21.11^{\circ} \mathrm{C}\left(70^{\circ} \mathrm{F}\right)$. 
16. The ambient pressure is sea level ( 1 atmosphere absolute).

17. The pump inlets have a $2^{\circ} \mathrm{C}$ minimum sub-cooling to protect against cavitation.

18. The high-efficiency compressors and turbines have an efficiency of $90 \%$.

19. The steam generators have a minimum approach temperature of $50^{\circ} \mathrm{C}$.

20. The HTGR primary recirculator has an efficiency of $75 \%$. 


\section{POWER GENERATION}

One of the primary functions of a nuclear reactor is to produce electricity, a process that generally consists of four stages: (1) heat addition, (2) power generation through expansion, (3) heat rejection, and (4) compression. In a direct power cycle, the working fluid directly cools the core of the nuclear plant. Direct power cycles provide more electrical power per unit of heat generated from the core, but contaminate the power cycle components with radioactive materials. In an indirect power cycle, the working fluid and the primary cooling loop of the reactor core are separate (requiring heat addition from the core to be provided by a steam generator or intermediate heat exchanger). This report examines four indirect power cycles:

- A conventional natural gas combined cycle (NGCC)

- A Rankine steam cycle

- An Brayton helium gas cycle with process heat

- A combined Rankine/Brayton cycle with/without process heat.

The power generation cycles analyzed in this study are illustrated in Figure 3 as simplified flow sheet diagrams. 


\section{Carbon Reduction Gains for Nuclear-Integrated Power Generation Processes (modeled cases)}

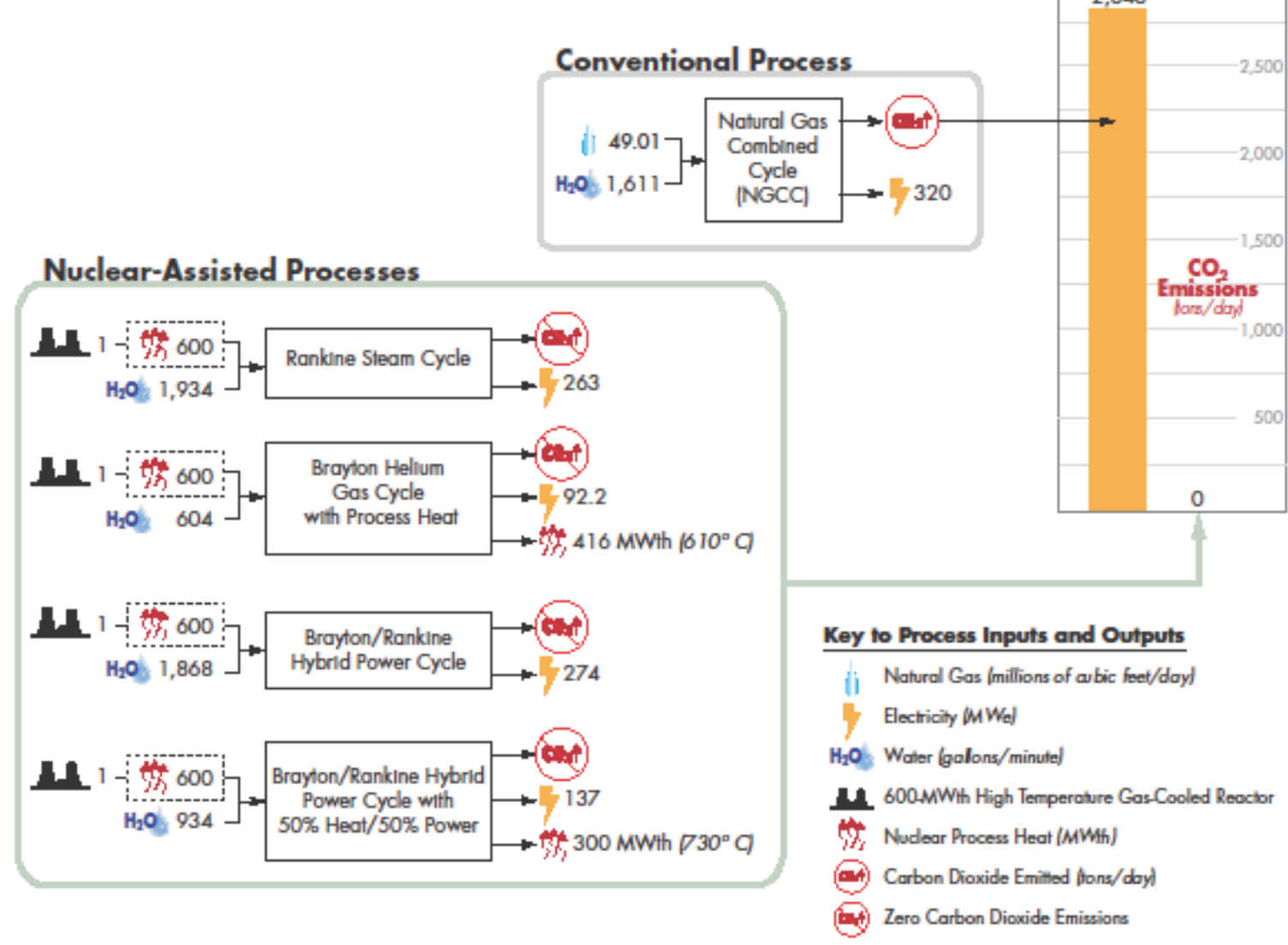

Figure 3. An illustration of the power generation cycles analyzed in this study shows that carbon dioxide reductions can be gained by using a nuclear-integrated process. The conventional case is shown as a basis for comparison.

\subsection{Power Generation - Cases Evaluated}

NGCC was selected as the basis for comparison, because it is one of the most efficient power cycles currently used. NGCC production capacity was set at $600 \mathrm{MWth}$. The nuclear-integrated cases that were studied included the Rankine cycle, the Brayton cycle, and a combined Rankine/Brayton hybrid cycle.

The Rankine cycle uses steam as the working fluid. For the analysis, the maximum pressure of the steam was set to 24 megapascals (MPa) (a design pressure for existing Rankine cycles) and the maximum temperature of the steam was set to $550^{\circ} \mathrm{C}$ (a limitation set by the temperature constraints on the steam generator).

The Brayton helium gas cycle uses helium as the working fluid. For the analysis, the maximum pressure of the helium was set to $7 \mathrm{MPa}$; the maximum temperature of the helium was set to $730^{\circ} \mathrm{C}$. The reactor exit temperature was set to $750^{\circ} \mathrm{C}$; the reactor exit pressure was set to $7 \mathrm{MPa}$. The cycle was optimized for heat recuperation, which produced almost 100 MWe and more than $400 \mathrm{MWth}$ of process heat at $610^{\circ} \mathrm{C}$.

The Brayton/Rankine hybrid power cycle, a derivative of both cycles, uses process heat from the Brayton cycle to produce steam for the Rankine cycle. Any fraction of the reactor heat can be used for process heat. The hybrid cycle can be configured to efficiently produce several different fractions of electricity and process heat. For the analysis, the combined hybrid cycle case was configured two ways: 
(1) to produce $100 \%$ electricity, and (2) to produce $50 \%$ electricity with the remaining $50 \%$ reactor heat offered as process heat. The process heat was set at a temperature of $730^{\circ} \mathrm{C}\left(130^{\circ} \mathrm{C}\right.$ higher than the process heat from the Brayton cycle).

\subsection{Power Generation - Preliminary Evaluation}

Thermal efficiency, a measure of a power cycle's thermodynamic performance, was calculated for each power cycle evaluated. These are shown in Table 1.

Table 1. Thermal efficiencies for the evaluated power generation cycles.

\begin{tabular}{|l|c|}
\hline \multicolumn{1}{|c|}{ Evaluated Power Generation Cycles } & \multicolumn{1}{|c|}{$\begin{array}{c}\text { Thermal Cycle } \\
\text { Efficiency }^{2}\end{array}$} \\
\hline Natural Gas Combined Cycle & $53.4 \%$ \\
\hline Rankine Steam Cycle & $43.8 \%$ \\
\hline Brayton Helium Gas Cycle & $46.7 \%$ \\
\hline Brayton/Rankine Hybrid Cycle ${ }^{1}$ & $45.7 \%$ \\
\hline $\begin{array}{l}\text { 1. The thermal efficiency of the Brayton/Hybrid cycle remains the same, whether it is for } 100 \% \\
\text { electric power generation or 50\% power generation. } \\
\text { 2. Thermal efficiency is defined as the electrical power output divided by the heat input. }\end{array}$ \\
\hline
\end{tabular}

The NGCC cycle uses less water, produces more power, and has a higher thermal efficiency than the nuclear-integrated cases, as a result of high combustion temperatures. However, it produces 2,800 tons/day of carbon dioxide (see Figure 3).

The Rankine cycle has the lowest thermal efficiency of the cycles studied because it has a lower inlet temperature into the turbine. It uses the most water, which is due to having the highest ambient heat rejection.

The Brayton helium cycle has the highest thermal cycle efficiency, because it has a higher inlet temperature $\left(730^{\circ} \mathrm{C}\right)$ into the turbine. As a result, its water usage is lower than the other power cycles studied. However, the cycle cannot be used solely to produce electricity. Due to heat recuperation, its production is limited to $92 \mathrm{MWe}$.

Both of the Brayton/Rankine hybrid power cycles that were studied use almost as much water as the Rankine cycle, but they have a thermal efficiency of $45.7 \%$ - higher than the Rankine cycle, lower than the Brayton cycle. However, both hybrid power cycles produce more electricity than either the Rankine or Brayton cycles.

Of the nuclear processes studied, both the Rankine and Brayton/Rankine hybrid processes compare well with a conventional NGCC process, and the Brayton/Rankine hybrid process produces almost as much power as NGCC process. However, unlike the NGCC process, none of the nuclear processes produce carbon dioxide emissions. 


\section{HYDROGEN PRODUCTION}

Hydrogen is a key element used in making fuels and other industrial chemicals. The current technology for making hydrogen is steam reforming using natural gas. High-temperature steam electrolysis is the only alternative nuclear-integrated process considered for this study.

The steam reforming process was modeled using ASPEN PLUS, from methane reforming and gas shift, through cleanup and cooling. The HTGR-assisted HTSE process was modeled using HYSYS, because the software permits accurate mass and energy balances, and contains components like compressors, turbines, pumps, valves, and heat exchangers.

\subsection{Hydrogen Production - Cases Evaluated}

The current technology for making hydrogen is steam reforming using natural gas (shown as a block diagram in Figure 4). Water and methane feed the process. Some of the methane is used to make steam, a process called methane reforming. The remainder is combined with the steam to create hydrogen and carbon dioxide, a process called gas shift. Two basic chemical equations describe the process:

(1) Methane reforming: $\mathrm{CH}_{4}+\mathrm{H}_{2} \mathrm{O} \Leftrightarrow \mathrm{CO}+3 \mathrm{H}_{2}$

(2) Gas shift: $\mathrm{CO}+\mathrm{H}_{2} \mathrm{O} \Leftrightarrow \mathrm{CO}_{2}+\mathrm{H}_{2}$

\section{Hydrogen Production via} Steam-Reforming using Natural Gas
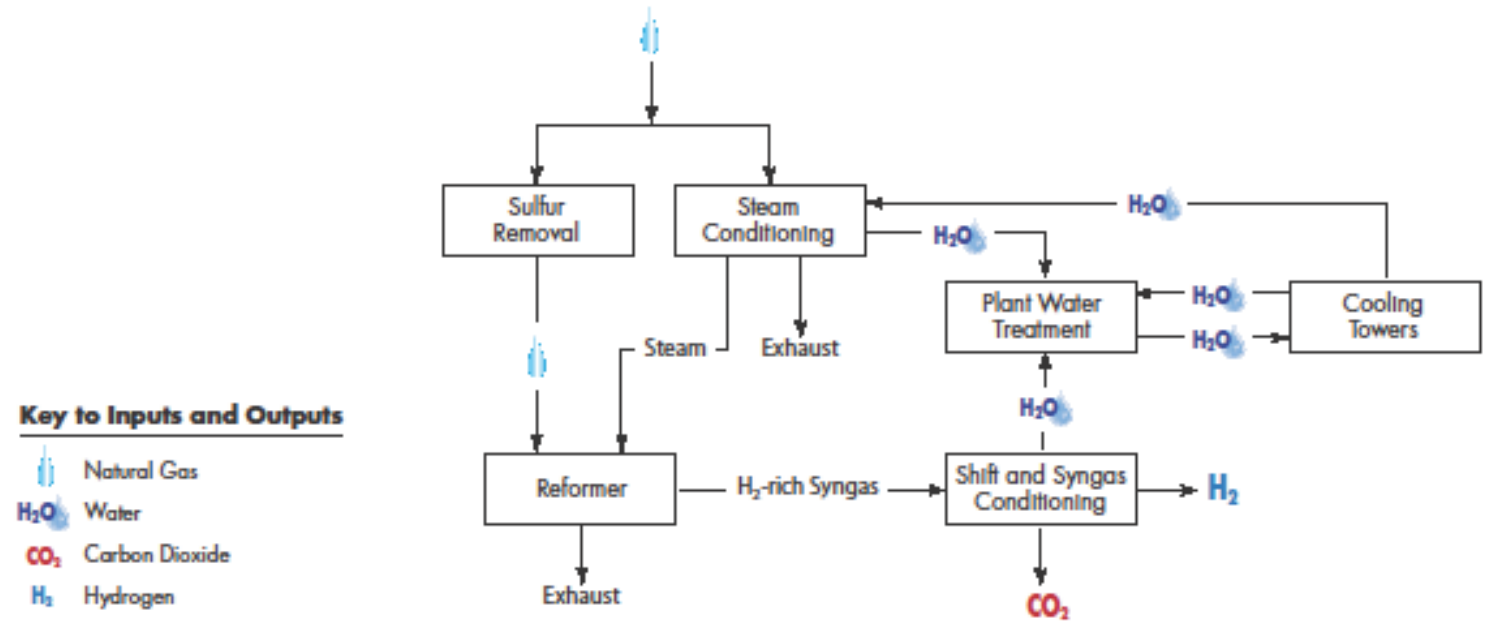

Figure 4. A block diagram illustrates steam reforming using natural gas, a conventional technology for hydrogen production.

The nuclear-integrated process evaluated in this study for making hydrogen is high-temperature steam electrolysis (HTSE) (shown as a block diagram in Figure 5). In this process, solid oxide electrolysis cells use heat from a high-temperature gas-cooled reactor and electrical power to split water and create hydrogen and oxygen. 


\section{Hydrogen Production via High-Temperature Steam Electrolysis}

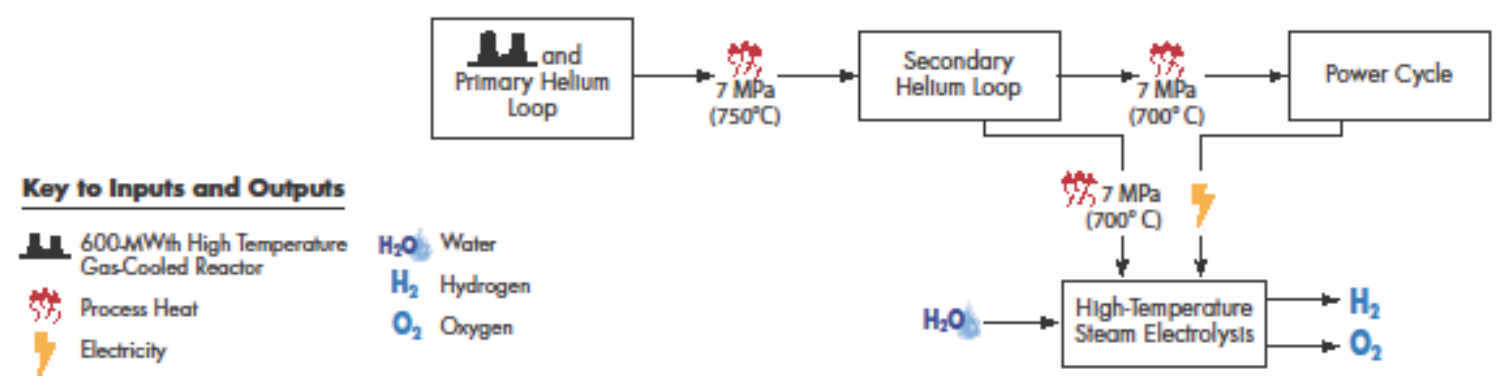

Figure 5. A block diagram illustrates hydrogen production using HTGR-assisted high-temperature steam electrolysis.

For the evaluation, both cases were adjusted to produce the typical daily output from steam reforming - 700 tons/day of hydrogen. To achieve this, a conventional steam reformer requires 2,000 tons/day of natural gas, $12 \mathrm{MW}$ of electricity, and 1,360 gallons/minute of water to supply steam and cooling. Besides hydrogen, a conventional steam reforming process produces 3,400 tons/day of carbon dioxide emissions. The hydrogen production cases analyzed in this study are illustrated in Figure 6 as simplified flow sheet diagrams.

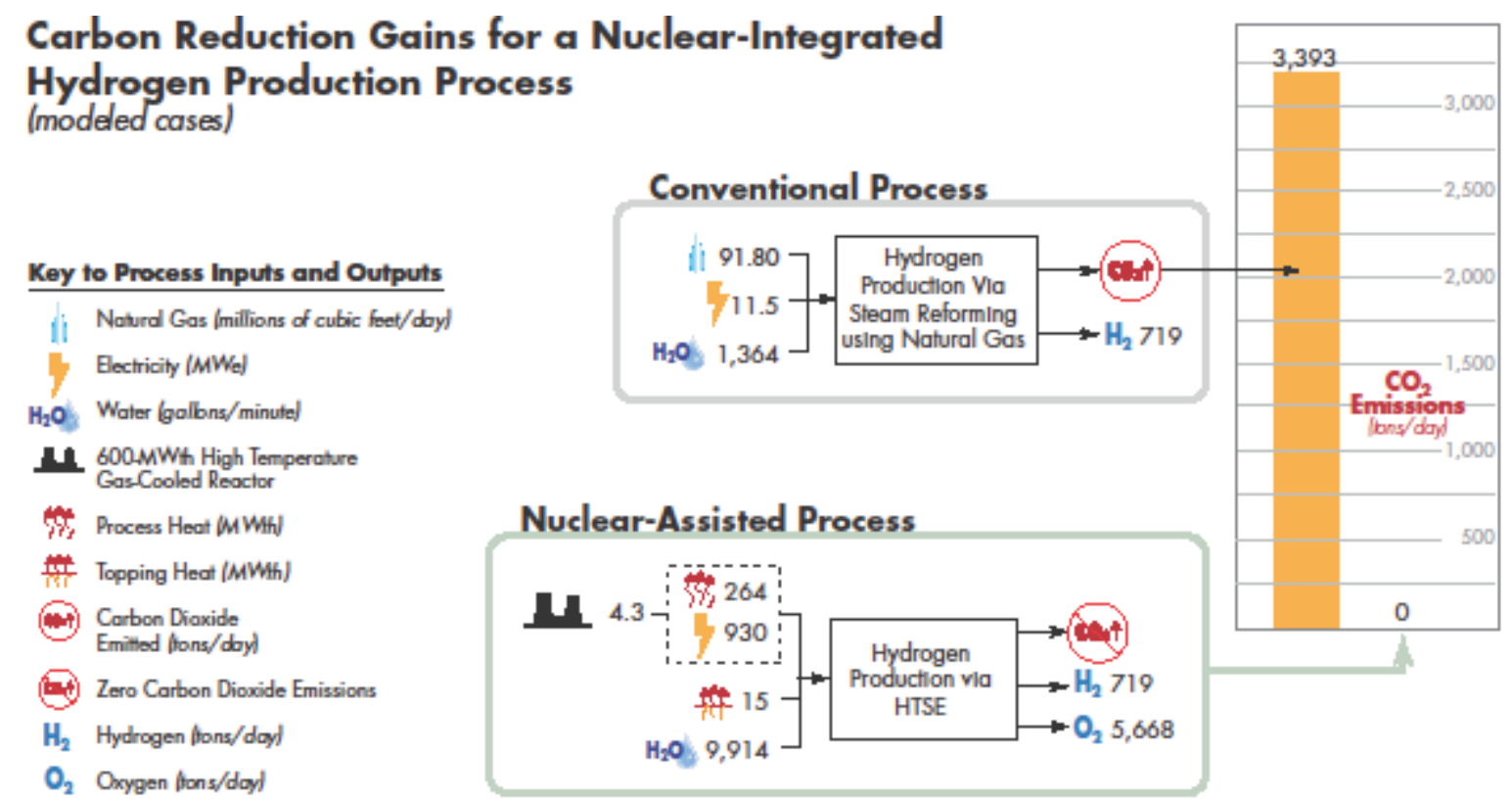

Figure 6. An illustration of the hydrogen production processes analyzed in this study shows that carbon dioxide reductions can be gained by using a nuclear-integrated process. The conventional case is shown as a basis for comparison. 


\subsection{Hydrogen Production - Preliminary Evaluation}

Hydrogen production efficiency was calculated for both processes. The hydrogen production efficiency of the conventional steam-reforming process is $79.4 \%$, greater than the $40.4 \%$ hydrogen production efficiency of nuclear-integrated HTSE process. For steam reforming, the hydrogen production efficiency is influenced primarily by the natural gas input; for HTSE, hydrogen production efficiency is influenced primarily by electrical power. The relative influences on efficiency can be seen in Table 1 . The HTSE process is very close to the power cycle efficiencies.

Nuclear-integrated HTSE requires much larger amounts of electricity and water than conventional steam reforming to achieve the same hydrogen output. It requires 4.3600 -MWth HTGRs to provide $930 \mathrm{MWe}$, primarily for electrolysis; $264 \mathrm{MWth}$ of process heat, primarily to produce the steam for electrolysis; and 9,914 gallons/minute of water, primarily for reactor cooling. The HTSE process also requires the feed stream to be heated to $700^{\circ} \mathrm{C}$. Because reactor and heat exchanger constraints limit process heat to $700^{\circ} \mathrm{C}, 15 \mathrm{MW}$ th (topping heat) is required from another heat source. This could be provided by a combustor or by waste heat from a neighboring process, such as one that uses hydrogen.

A major advantage of the HTSE process is that it produces oxygen, which may be used for other chemical processes, and no carbon dioxide emissions. In contrast, the conventional steam reforming process produces 3,393 tons of carbon dioxide emissions per day. Another major advantage of HTSE is that the hydrogen product is relatively contaminant free. As a result, it can be directly fed to a catalyst process without additional gas clean-up. Hydrogen produced via steam methane reforming contains residual condensable carbon and requires gas clean-up before it can be used in a catalyst process.

Note: Hydrogen production efficiency is defined as the thermal value of the hydrogen product divided by the sum of thermal value of the feed streams, process heat in, and thermal equivalent of the electric power. In essence, the efficiency is the thermal value of the hydrogen output divided by the thermal value of the input.

For steam reforming, the hydrogen production efficiency is the higher heating value of the hydrogen divided by the sum of the higher heating value of the natural gas and the thermal energy equivalent of the electrical power input. The thermal value of the electricity is found by the electrical power divided by the efficiency of the power cycle, which was conservatively assumed to be $40 \%$.

For HTSE, the hydrogen production efficiency is the higher heating value of the hydrogen product divided by the sum of the thermal energy of the electrical power used, the process heat from the reactor, and the topping heat. 


\section{CHEMICAL CYCLES}

This study examined conventional and potential HTGR-integrated processes in the following common industrial areas:

- Producing ammonia and ammonia-derived products, such as fertilizer

- Producing gasoline and diesel from natural gas or coal

- Producing substitute natural gas from coal

- Extracting oil from Canadian oil sands.

Steam-assisted gravity drainage models were developed in Excel spreadsheets. The remaining process models were developed with ASPEN PLUS process modeling software. The cases were analyzed to identify opportunities for integrating heat produced by an HTGR and for integrating hydrogen from high-temperature steam electrolysis.

In general, heat is provided to nuclear-integrated processes via steam. However, for reforming natural gas in the gas-to-ammonia and the gas-to-gasoline cases, helium was used to provide nuclear-integrated heat rather than steam. An assumption that applies to only the chemical cycles is that carbon dioxide has been captured where feasible, for example, when high concentrations of carbon dioxide are in the gas stream. While technologies are available for compressing carbon dioxide, the technology for storing carbon dioxide from an industrial plant has not yet been developed. Technology development costs for carbon sequestration are not included in this analysis nor will they be considered for Phase 2 of this work.

\subsection{Ammonia and Ammonia-Derived Products}

The models for coal-to-ammonia and natural gas-to-ammonia plants were structured to include the most common derivative products: nitric acid, ammonium nitrate, and urea. Because numerous endproduct mixes could be simulated by varying the ammonia flow to each of the downstream processes, the split of derivate products was adjusted to produce ammonium nitrate and urea in the right ratio for UAN 32 synthesis (urea ammonium nitrate solution containing $32 \mathrm{wt} \%$ nitrogen, made by combining ammonium nitrate, urea, and water in a 45/35/20 blend). All modeled cases produced 2,939 tons/day of urea and 3,779 tons/day of ammonium nitrate. HTGR electrical power generation efficiency was set at $40 \%$. The ammonia production cases analyzed in this study are illustrated in Figure 7 as simplified flow sheet diagrams. 


\section{Carbon Reduction Gains for Nuclear-Integrated Gas-to-Ammonia Derivatives Processes (modeled cases)}

\section{Conventional Processes}

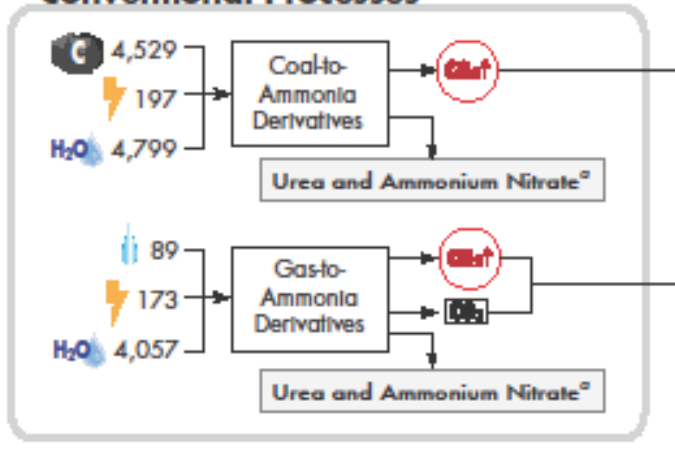

\section{Nuclear-Assisted Processes}

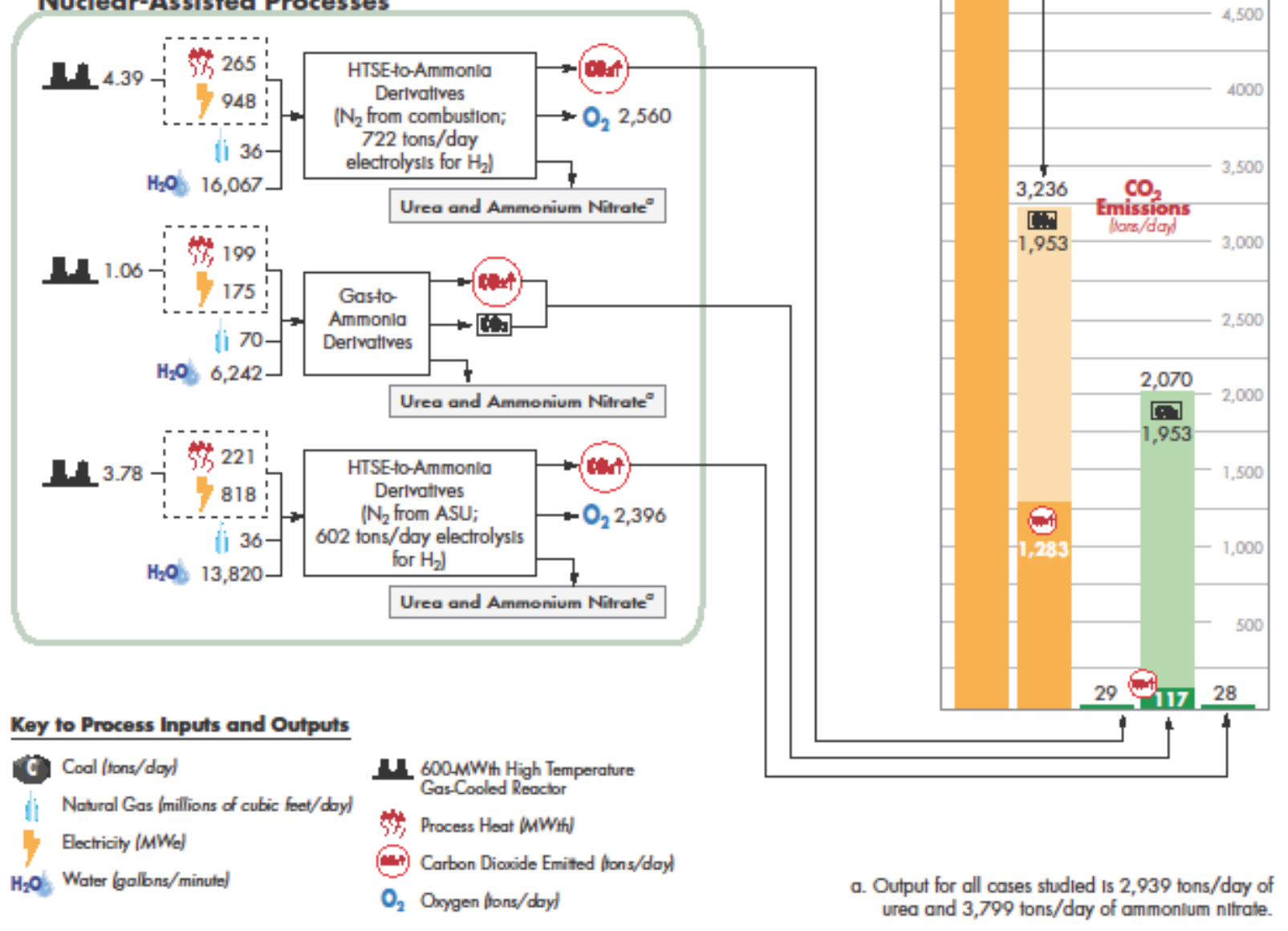

Figure 7. An illustration of the gas-to-ammonia derivatives processes analyzed in this study shows that carbon dioxide reductions can be gained by using a nuclear-integrated process. The conventional cases are shown as a basis for comparison.

\subsubsection{Ammonia Production - Cases Evaluated}

The analysis of the conventional natural gas-to-ammonia plant indicates a strong potential for heat integration. In the conventional plant, $21.3 \%$ of the natural gas feed to the process is burned to provide 
heat to the primary reformer. The operating temperature in the primary reformer is $725^{\circ} \mathrm{C}$, which is very close to the assumed $700^{\circ} \mathrm{C}$ temperature that can be supplied by an HTGR. The analysis indicates that the primary reformer temperature can be lowered slightly without negative effects, which would allow nuclear heat to be substituted directly for natural gas combustion.

The analysis of the inputs shows that hydrogen could be provided by HTSE. (See page 9 for a discussion of HTSE.) Neither natural gas nor coal is required because ammonia does not contain carbon. The nitrogen for ammonia synthesis can be supplied either by (1) cryogenic air separation, or (2) combustion in air of a portion of the hydrogen, followed by cooling/condensation to remove water. Both options were modeled. Urea manufacture requires carbon dioxide as a feed to the process, so a small carbon source is required. This can be supplied by burning natural gas in oxygen (a readily available HTSE byproduct) or using coal, but natural gas has simpler gas cleanup requirements.

The initial analysis of the conventional coal-to-ammonia process indicates no need for high-temperature heat integration, particularly because light water reactors can supply power. As a result, modeling of a nuclear-integrated coal-to-ammonia case was not pursued. Other gasification technologies, such as hydrogasification, may be a better prospect for HTGR integration. The calculated carbon dioxide emissions from the conventional coal-to-ammonia process were compared to the nuclear-integrated natural gas case.

\subsubsection{Ammonia Production - Preliminary Evaluation}

Overall, the results for the nuclear-integrated natural gas-to-ammonia case look promising. Using a conservative nuclear power cycle efficiency of $40 \%$, this configuration could be supported with just over one 600-MWth HTGR. If the power cycle efficiency is increased to $45 \%$, a single HTGR would be sufficient to support operation. The split of heat to power required from the nuclear plant is $31 \% / 69 \%$, which is very attractive for design of the nuclear cycle.

Substituting nuclear heat for natural gas combustion in the primary reformer would reduce natural gas consumption by more than $20 \%$. Carbon dioxide emissions would be reduced by more than $90 \%$. The water consumption value appears higher in the nuclear-integrated case than the conventional case, but the value in the nuclear-integrated case includes all power generation required by the facility. In contrast, the conventional case requires the importation of $175 \mathrm{MWe}$, and the water consumption needed to generate this electricity is not included in the plant water balance.

The results for the two HTSE hydrogen cases also look promising. They show a marked increase in water consumption, but natural gas consumption can be reduced to the amount required to supply carbon for urea production. Carbon dioxide emissions are reduced to very low levels, and the need to sequester carbon is eliminated. Both configurations would require roughly four 600-MWth HTGRs to support plant operation. The overall attractiveness of these configurations hinges on the planned detailed economic analysis and lifecycle greenhouse gas emissions evaluation. Of the two cases considered, the option utilizing cryogenic air separation for nitrogen production appears to be more attractive from the perspectives of cost and water consumption.

\subsection{Natural Gas-to-Liquids and Coal-to-Liquids}

The models for the natural gas-to-liquids and coal-to-liquids plants were constructed with plant production capacity set at 50,000 barrels per day of liquid products (diesel, naphtha, and LPG). The nuclear-integrated cases were adjusted to produce the same liquid fuel output as the conventional cases. The natural gas composition was taken from data published by Northwest Gas Association. HTGR electrical power generation efficiency was set at 40\%. A generic Illinois \#6 coal was utilized for the coalto-liquids cases. Figure 8 illustrates the coal-to-liquids and gas-to-liquids cases evaluated in this study as simplified flow sheet diagrams. 


\section{Carbon Reduction Gains for Nuclear-Integrated Natural Gas-to-Liquids or Coal-to-Liquids Processes (modeled cases)}
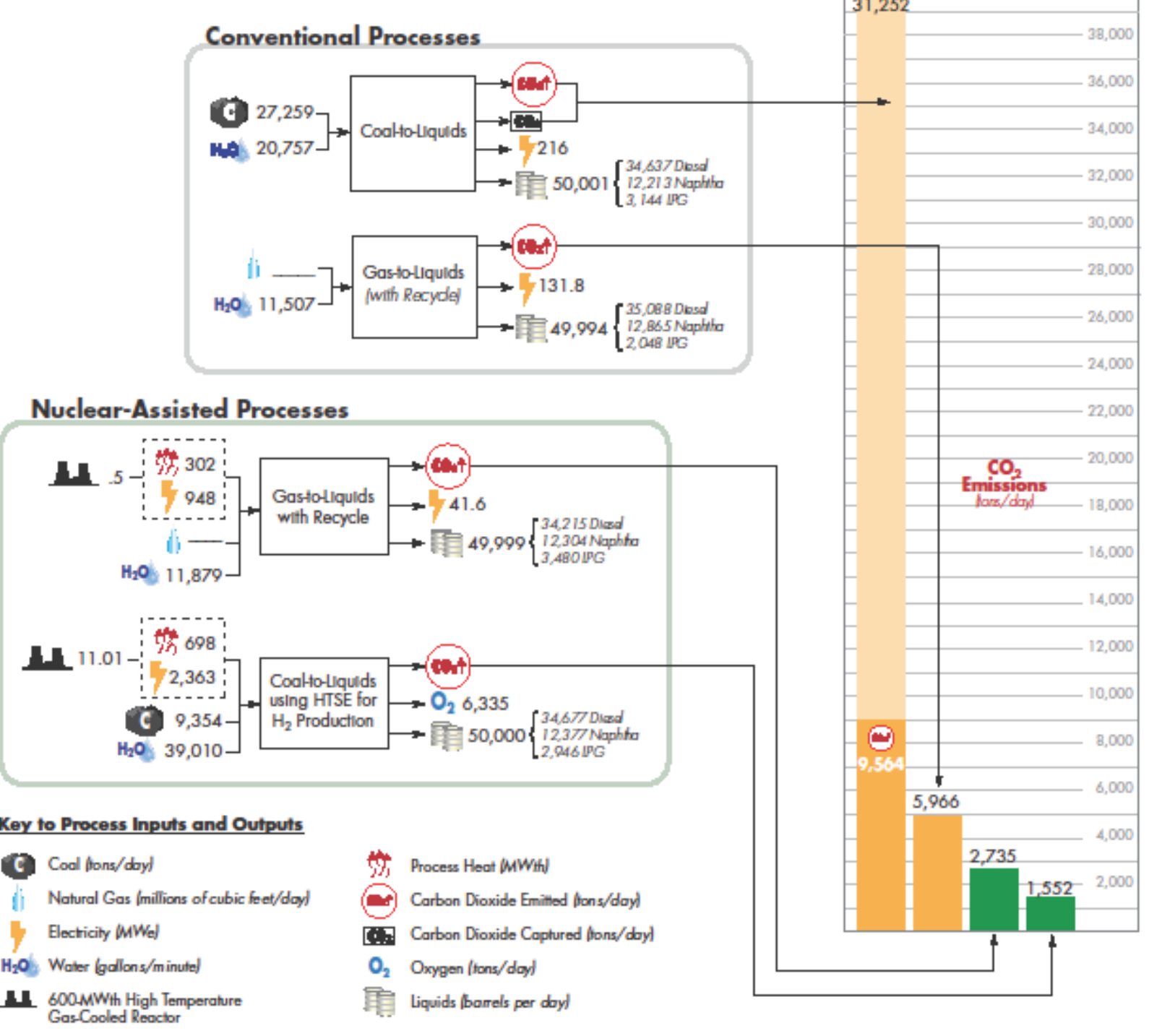

Figure 8. An illustration of the coal-to-liquids and gas-to-liquids cases analyzed in this study shows that carbon dioxide reductions can be gained by using a nuclear-integrated process. The conventional cases are shown as a basis for comparison.

\subsubsection{Natural Gas-to-Liquids and Coal-to-Liquids - Cases Evaluated Natural gas-to-Liquids}

The analysis of the conventional natural gas-to-liquids plant indicated a strong opportunity for high-temperature heat integration. In a conventional plant, $13.3 \%$ of the natural gas feed is burned to provide heat to the primary reformer. The operating temperature in the primary reformer is $730^{\circ} \mathrm{C}$, which is very close to the assumed $700^{\circ} \mathrm{C}$ temperature that can be supplied by an HTGR. The analysis indicated that the temperature of the primary reformer can be lowered slightly without negative effect, which would allow nuclear heat to be substituted for natural gas combustion. For the analysis of the conventional and nuclear natural gas-to-liquids cases, it was assumed that light gas would be recycled back to the reformer. 


\section{Coal-to-Liquids}

The initial analysis of the conventional coal-to-liquids plant showed that the process produces heat beyond what is needed to support plant demands. As a result, a nuclear-integrated model was developed that focuses primarily on integrating nuclear hydrogen rather than nuclear heat.

The analysis of the conventional coal-to-liquids plant also indicates an opportunity for hydrogen supplementation using HTSE. (See page 9 for a discussion of HTSE.) An external hydrogen source would eliminate the need to "shift" the syngas using conventional water-gas shift reactors. The primary benefit of this change would be a reduction in greenhouse gas emissions from the process.

\subsubsection{Natural Gas-to-Liquids or Coal-to-Liquids Production — Preliminary Evaluation}

The results for the nuclear-integrated natural gas-to-liquids case look promising. Only half of a 600-MWth HTGR would be required and the reactor would supply only heat to the fossil process because more power is generated in the process than is required. Production capacity is $50,000 \mathrm{bbl} /$ day. Water consumption increases slightly, just 3.2\%. Substituting nuclear heat for natural gas combustion in the primary reformer decreases natural gas consumption by $13.3 \%$. Power production for the plant decreases from 131.8MW for the conventional case to $41.6 \mathrm{MW}$ for the nuclear-integrated case. This occurs because of reduced output from the steam turbines due to removing the hot exhaust stream from the natural gas burner for the primary reformer. Carbon dioxide emissions from the plant would decrease by $55 \%$.

In the nuclear-integrated coal-to-liquids case, nuclear energy is used to offset a portion of the energy requirement derived from coal. It is estimated that eleven 600-MWth HTGRs (6.6 GWth) would be required in this configuration to support production. Power consumption increases from producing 216 MW (in the conventional case) to consuming 2,362 MW (in the nuclear-integrated case). However, integrating HTSE to supplement hydrogen dramatically improves carbon utilization and decreases coal consumption by $66 \%$. The carbon fraction in the coal partitioned to the liquid fuel products increases from $31.3 \%$ to $91.4 \%$.

Most dramatically, integrating nuclear power and HTSE in the coal-to-liquids process decreases carbon dioxide emissions. If carbon capture and sequestration are assumed for the baseline configuration, carbon dioxide emissions decrease by $84 \%$. If carbon capture and sequestration are not assumed for the baseline configuration, carbon dioxide emissions decrease by $96 \%$.

\subsection{Natural Gas-to-Methanol-to-Gasoline and Coal-to-Methanol-to-Gasoline}

The models for the natural gas-to-methanol-to-gasoline cases were constructed with plant production capacity set at 10,000 tonnes/day of methanol, which corresponds to dual 5,000 tonnes/day methanol plants. The final product rate for the cases was 38,750 bbl/day of liquid products (gasoline plus LPG). The capacity for the nuclear-integrated case was adjusted to produce the same liquid fuel output as the conventional case. Natural gas composition was taken from data published by Northwest Gas Association.

The models for the coal-to-methanol-to-gasoline cases were constructed with plant production capacity set at 70,800 bbl/day of liquid products (gasoline plus LPG). The capacity for the conventional facility was set assuming six gasifiers, operating at a capacity of 3,600 tonnes/day each. A generic

Illinois \#6 coal was used. The capacity for the nuclear-integrated case was adjusted to produce the same liquid fuel output as the conventional case. HTGR electrical power generation efficiency was set at $40 \%$.

Figure 9 illustrates the natural gas-to-methanol-to-gasoline and coal-to-methanol-to-gasoline cases evaluated in this report as simplified flow sheet diagrams. 
Carbon Reduction Gains for Nuclear-Integrated Natural Gas-to-Methanol-to-Gasoline and Coal-to-Methanol-to-Gasoline Processes (modeled cases)

\section{Conventional Processes}

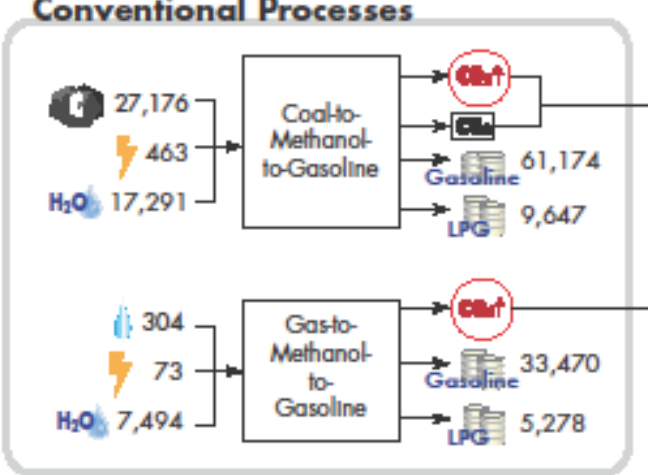

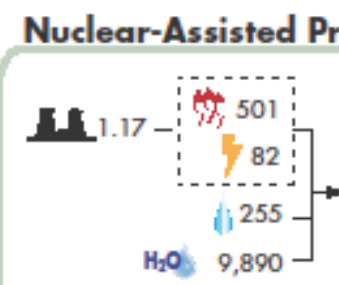

Processes

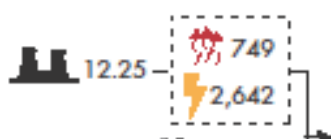

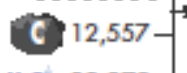

$\mathrm{H}_{2} \mathrm{O}, 38,975$
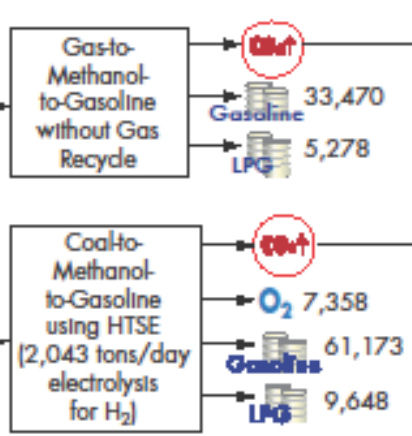

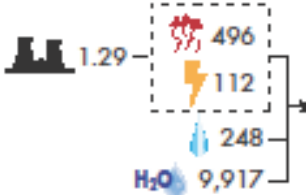

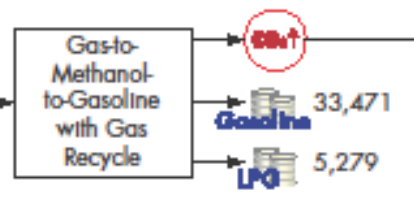

Key to Process Inputs and Outputs

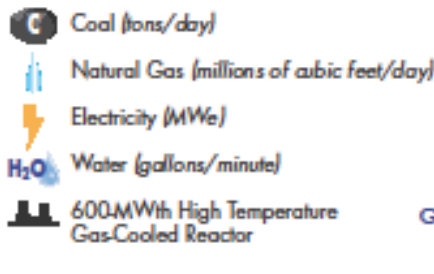

St. Process Heat (MWh)

(Carbon Diaxide Emitted Atons/dayl

E.: Carbon Diaxide Captured /bns/day)

$\mathrm{O}_{2}$ Oxygen fons/day)

Gasoline Gasoline (barels per day)

LPG Liquified Petroleum Gas (borrels per day)

Figure 9. An illustration of the gas-to-methanol-to-gasoline and coal-to-methanol-to-gasoline cases analyzed in this study shows that carbon dioxide reductions can be gained by using a nuclear-integrated process. The conventional cases are shown as a basis for comparison. 


\subsubsection{Natural Gas-to-Methanol-to-Gasoline and Coal-to-Methanol-to-Gasoline - Cases Evaluated}

\section{Natural Gas-to-Methanol-to-Gasoline}

Two cases of the nuclear-integrated natural gas-to-methanol-to-gasoline process were modeled. In one case, the process was coupled with an HTGR to supply reforming heat. In the other, the process was equivalent, with the addition of a recycle of light gas back to the reformer.

The analysis of the conventional natural gas-to-methanol-to-gasoline plant indicated a strong opportunity for heat integration supplied by an HTGR. In the conventional plant, $17.7 \%$ of the natural gas feed is burned to provide heat to the primary reformer. The operating temperature in the primary reformer is $730^{\circ} \mathrm{C}$, which is very close to the assumed $700^{\circ} \mathrm{C}$ temperature that can be supplied by an HTGR. The analysis appears to indicate that the primary reformer temperature can be lowered slightly without negative effect, which in turn indicates that nuclear heat can be substituted for natural gas combustion.

\section{Coal-to-Methanol-to-Gasoline}

The analysis of the conventional coal-to-methanol-to-gasoline plant indicated an opportunity for hydrogen supplementation using HTSE. (See page 9 for a discussion of HTSE.) An external hydrogen source would eliminate the need to "shift" the syngas using conventional water-gas shift reactors. The primary benefit of this change would be a reduction in greenhouse gas emissions from the process.

It was also determined that the conventional coal-to-methanol-to-gasoline plant produces heat beyond what is needed to support demands of the plant. Based on these observations, a nuclear-integrated model was developed that focuses primarily on integrating nuclear hydrogen rather than nuclear heat.

\subsubsection{Natural Gas-to-Methanol-to-Gasoline and Coal-to-Methanol-to-Gasoline - Preliminary Evaluation}

Results for the nuclear-integrated gas-to-methanol-to-gasoline cases look promising. Using a conservative nuclear power cycle efficiency of $40 \%$, these configurations would require just over one 600-MWTh HTGR. For both the nuclear-integrated nonrecycle and recycle cases, the heat-to-power ratios are attractive, $71 \% / 29 \%$ in the nonrecycle case decreasing to $64 \% / 36 \%$ in the recycle case. Substituting nuclear heat for natural gas combustion in the primary reformer decreases natural gas consumption by $16 \%$ in the nonrecycle case and by $18 \%$ in the recycle case. Compared to the conventional case, the power requirements for the plant increase from 73.3 MWe in the conventional case to $79.6 \mathrm{MWe}$ in the nonrecycle case, then sharply higher to $109.7 \mathrm{MWe}$ in the recycle case. The primary factor for the increased power consumption in the recycle case is reduced output from the steam turbines due to the reduction in fuel gas available to fire in the heat recovery steam generator. The nuclear-integrated cases show higher water consumption values than the conventional case because the nuclear-integrated cases include all power generation required by the facility. In contrast, the conventional case does not include the water consumption required to generate the $73.3 \mathrm{MWe}$ that is imported for the process.

Most dramatically, however, integrating nuclear power and HTSE decreases carbon dioxide emissions - by $81 \%$ for the nonrecycle case and by $93 \%$ for the recycle case.

In the nuclear-integrated coal-to-methanol-to-gasoline cases, nuclear energy is used to offset a portion of the energy requirement derived from coal. This is evident, as power consumption is increased from $463 \mathrm{MWe}$ to $2642 \mathrm{MWe}$, an increase of $466 \%$. It is estimated that thirteen 600-MWt HTGRs would be required in this configuration to support production. The results also indicate that integration of nuclear hydrogen can dramatically improve carbon utilization. Using electrolysis and nuclear power as the hydrogen source decreases coal consumption by $54 \%$. The carbon fraction in the coal partitioned to the liquid fuel products increases from $45.1 \%$ to $97.6 \%$ for the nuclear-integrated case. 
Again, the results show that integrating nuclear power and HTSE decreases carbon dioxide emissions. If carbon capture and sequestration are assumed for the baseline configuration, carbon dioxide emissions decrease only by $18 \%$. However, if carbon capture and sequestration are not assumed for the baseline configuration, carbon dioxide emissions decrease by $98.7 \%$.

\subsection{Coal-to-Substitute Natural Gas}

The models for the coal-to-substitute natural gas cases were constructed with plant production capacity set to produce 50 million standard cubic feet per day (MMSCFD) of substitute natural gas. The capacity for the nuclear-integrated case was adjusted to produce the same output. A generic Illinois \#6 coal was utilized.

\subsubsection{Coal-to-Substitute Natural Gas - Cases Evaluated}

The analysis of the conventional coal-to-substitute natural gas plant indicated an opportunity for hydrogen supplementation using HTSE. (See page 9 for a discussion of HTSE.) An external hydrogen source would eliminate the need to "shift" the syngas using conventional water-gas shift reactors. The primary benefit of this change would be a reduction in greenhouse gas emissions from the process.

It was also determined that the conventional coal-to-substitute natural gas case produces heat beyond what is needed to support demands of the plant. Based on these observations, a nuclear-integrated model was developed that focuses primarily on integrating nuclear hydrogen rather than nuclear heat.

Figure 10 illustrates the coal-to-substitute natural gas cases evaluated in this report as simplified flow sheet diagrams.

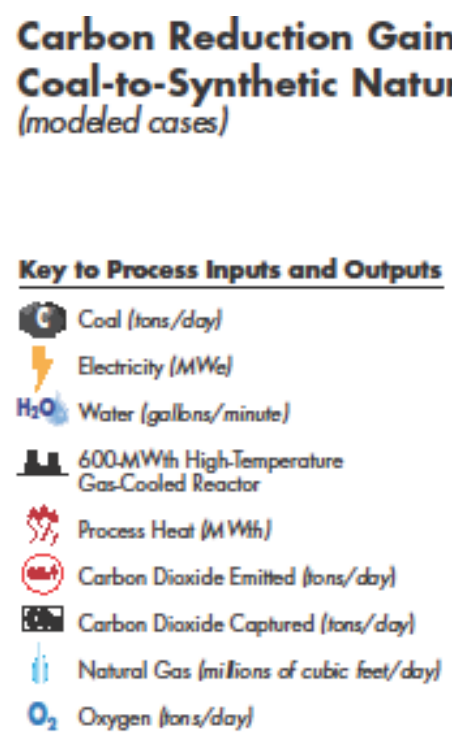

Figure 10. An illustration of the coal-to-substitute natural gas cases analyzed in this study shows that carbon dioxide reductions can be gained by using a nuclear-integrated process. The conventional case is shown as a basis for comparison.

\subsubsection{Coal-to-Substitute Natural Gas - Preliminary Evaluation}

In the nuclear-integrated case, nuclear energy is used to offset a portion of the energy requirement derived from coal. This is evident, as power consumption is increased from $36 \mathrm{MWe}$ to $398 \mathrm{MWe}$. It is estimated that a little less than two 600-MWt HTGRs would be required in this configuration to support production. 
The results indicate that integration of nuclear hydrogen can dramatically improve carbon utilization. Using electrolysis and nuclear power as the hydrogen source decreases coal consumption by $65 \%$. The carbon fraction in the coal partitioned to the liquid fuel products increases from $34.7 \%$ to $99.6 \%$.

Most dramatically, integrating nuclear power and HTSE decreases carbon dioxide emissions. If carbon capture and sequestration are assumed for the baseline configuration, carbon dioxide emissions decrease by $98.8 \%$. However, if carbon capture and sequestration are not assumed for the baseline configuration, carbon dioxide emissions decrease by $99.98 \%$. In other words, carbon dioxide emissions are essentially eliminated.

\subsection{Steam-Assisted Gravity Drainage (Canadian Oil Sands)}

Steam-assisted gravity drainage is the primary in situ technology used to recover bitumen from Canadian oil sands for subsequent upgrading to synthetic crude oil. Using a combination of steam injection and recovery wells, existing oil sand reservoirs are tapped by using parallel pairs of wells drilled horizontally at least 50 meters below land surface. Steam is injected into the top horizontal well. The steam melts the bitumen and it flows from the formation into the lower horizontal well where it is collected and brought to the surface. Each SAGD well pair has the potential to recover 2,000 barrels per day.

For the conventional case, combustion of fossil fuels provides the heat needed to generate steam. Nuclear heat would be utilized to generate steam for the nuclear-integrated case. For the nuclearintegrated case, the model accounts for thermal parasitic losses from the heat exchangers and the heat losses that occur when steam is transferred over relatively long distances between the second and third heat exchangers. Figure 11 illustrates the steam-assisted gravity drainage cases evaluated in this report as simplified flow sheet diagrams.

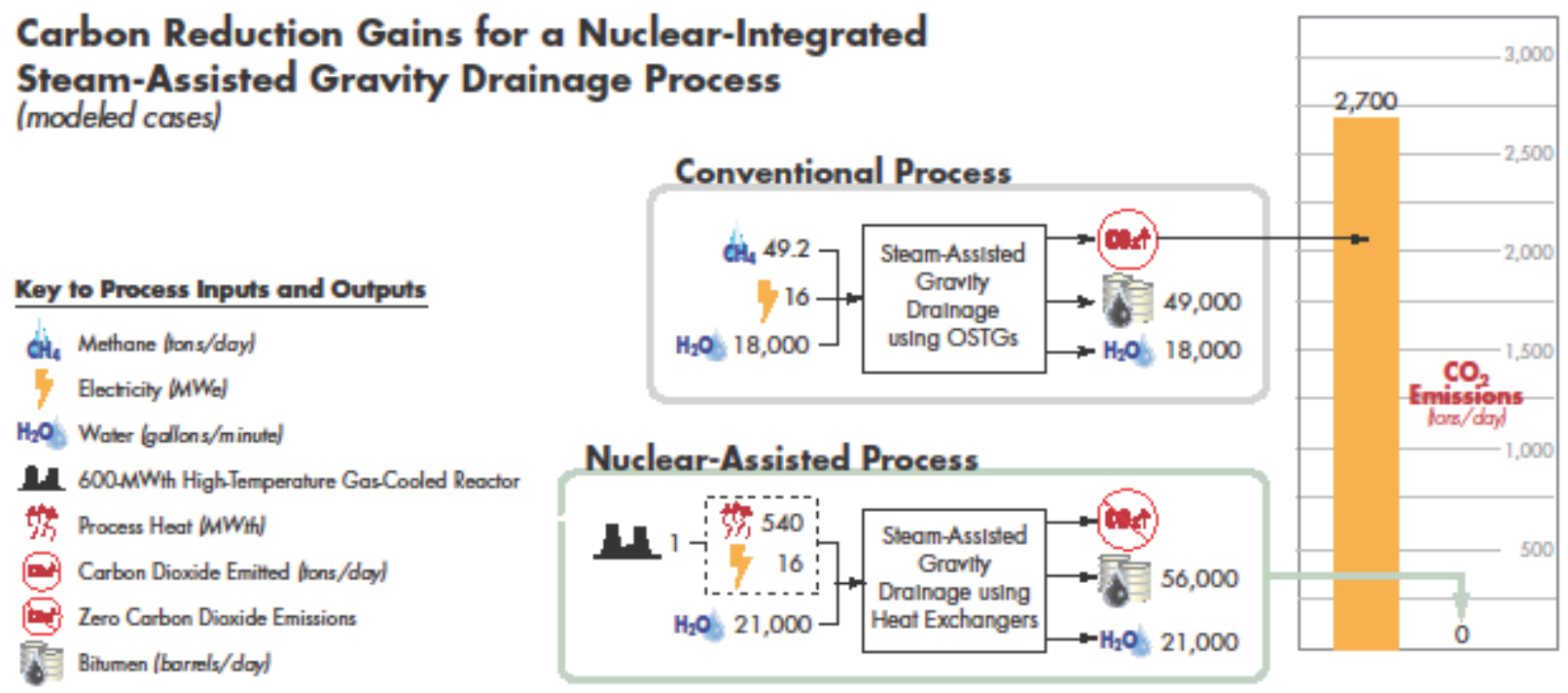

Figure 11. An illustration of the steam-assisted gravity drainage cases analyzed in this study shows that carbon dioxide reductions can be gained by using a nuclear-integrated process. The conventional case is shown as a basis for comparison.

\subsubsection{Steam-Assisted Gravity Drainage (Canadian Oil Sands) - Cases Evaluated}

A typical bitumen recovery operation includes a processing facility-steam boilers, an oil/bitumenwater separation system, and a water treatment train — surrounded by a number of well pairs on well pads, 
which are located within five kilometers of the facility. Methane is used to heat steam in a once-through steam generator (OTSG).

A Brayton helium gas power cycle, with a relatively higher efficiency of $45 \%$, was used for the nuclear case. One 600-MWth HTGR provides the heat required to generate steam for in situ bitumen recovery, offsetting the energy requirement derived from the combustion of methane in the conventional process. The HTGR also provides power for its own house load (most consumed by a helium circulator) and for the pump that transfers the steam condensate from the third well-pad nuclear HX/steam generator back to the process heat exchanger. In this case, the heat required to make steam for injection into the wells is transferred via a series of three heat exchangers. The first heat exchanger transfers heat from the helium circulating in the reactor core to produce steam. The steam is transferred to the second heat exchanger, which functions as a radiological safety barrier, and its output stream is transferred to the well pad, which may lie up to five kilometers away. There, the heat is transferred in a third exchanger that is designed to meet the steam pressure, temperature, and quality requirements necessary for productive bitumen recovery.

\subsubsection{Steam-Assisted Gravity Drainage - Preliminary Evaluation}

Initial baseline modeling results indicate that nuclear-integrated steam-assisted gravity drainage provides favorable methane fuel savings as well as a significant reduction in carbon dioxide emissions.

However, further economic analysis is needed to estimate a fundamental return on an HTGR investment. Consideration will need to be given to the volatile prices of conventional crude and natural gas, the future costs of methane, and the impacts of a carbon tax or cap-and-trade policies, including potential future carbon costs. 


\section{CONCLUSIONS}

This HTGR process integration study illustrates potential environmental benefits of providing clean heat, hydrogen, oxygen, and electricity to improve the yield and carbon dioxide emissions of several primary U.S. chemical and fuels industries. Carbon dioxide emission reductions ranged from $54 \%$ to $100 \%$ compared to conventional processes. The process comparisons summarized in Table 2 provide the basis for Figure 1. The case studies provide a preliminary understanding of the HTGR capacity that can be integrated into the specific case studies. The present examples illustrate the potential beneficial impacts of hybrid energy systems that (1) improve energy security by increasing the use of domestic sources, and (2) significantly reduce carbon dioxide emissions.

Table 2. The calculated reduction in carbon dioxide emissions for each industrial/chemical process. The results are based on a comparison of HTGR-integrated processes with conventional processes. The carbon dioxide emissions are not comparable. Some processes produce secondary products, such as excess electricity and oxygen.

\begin{tabular}{|c|c|c|c|c|}
\hline $\begin{array}{c}\text { Industrial } \\
\text { Areas }\end{array}$ & $\begin{array}{c}\text { Conventional } \\
\text { Process } \\
\end{array}$ & $\begin{array}{c}\text { Main Products (from } \\
\text { conventional and HTGR- } \\
\text { integrated) }\end{array}$ & $\begin{array}{c}\mathrm{CO}_{2} \text { Emissions } \\
\text { Eliminated (per } \\
\text { unit product) }\end{array}$ & $\begin{array}{c}\text { Reduction in } \mathrm{CO}_{2} \text { Emissions } \\
\text { (tons/day) }\end{array}$ \\
\hline $\begin{array}{l}\text { Power } \\
\text { Generation }\end{array}$ & Natural Gas & $320 \mathrm{MWe}$ & $\begin{array}{l}8.9 \text { tons } \\
\text { MWe/day }\end{array}$ & $\begin{array}{l}2,843 \\
\text { (HTGR-integrated Brayton/Rankin } \\
\text { hybrid power cycle) }\end{array}$ \\
\hline $\begin{array}{l}\text { Hydrogen } \\
\text { Production }\end{array}$ & $\begin{array}{l}\text { Methane Steam } \\
\text { Reform }\end{array}$ & $\mathrm{H}_{2}: 719$ tons/day & 4.7 tons/ton $\mathrm{H}_{2}$ & $\begin{array}{l}\text { 3,393 } \\
\text { (HTGR-integrated HTSE) }\end{array}$ \\
\hline $\begin{array}{l}\text { Ammonia } \\
\text { Production }\end{array}$ & Natural Gas & $\begin{array}{l}\text { Urea: } 2,939 \text { tons/day } \\
\text { Ammonium Nitrate: } 3,779 \\
\text { tons/day }\end{array}$ & $\begin{array}{l}0.40 \text { tons/ton } \\
\text { urea }\end{array}$ & $\begin{array}{l}1,166 \\
\text { (HTGR-integrated HTSE with } \mathrm{N}_{2} \\
\text { from ASU) }\end{array}$ \\
\hline $\begin{array}{l}\text { Ammonia } \\
\text { Production }\end{array}$ & Coal & $\begin{array}{l}\text { Urea }-2,939 \text { tons/day } \\
\text { Ammonium Nitrate }-3,779 \\
\text { ton/day }\end{array}$ & 2.6 tons/ 1 ton urea & $\begin{array}{l}7,735 \\
\text { (as compared to } \\
\text { nuclear-integrated } \\
\text { ammonia natural } \\
\text { gas process) }\end{array}$ \\
\hline $\begin{array}{l}\text { Natural Gas } \\
\text { to Liquids }\end{array}$ & Natural Gas & $\begin{array}{l}\text { Diesel: } 34,365 \text { bbl/day } \\
\text { Naptha: 12,277 bbl/day } \\
\text { LPG: } 3,359 \text { bbl/day } \\
\text { Processes with Secondary } \\
\text { Outputs: } \\
\text { Natural gas: } 131.8 \mathrm{MWe} \\
\text { HTGR: } 41.6 \mathrm{MWe}\end{array}$ & $\begin{array}{l}0.06 \text { tons/ } \\
\text { bbl liquids }\end{array}$ & $\begin{array}{l}3,231 \\
\text { (HTGR-integrated gas-to-liquids } \\
\text { with recycle) }\end{array}$ \\
\hline $\begin{array}{l}\text { Coal to } \\
\text { Liquids }\end{array}$ & Coal & $\begin{array}{l}\text { Diesel: } 35,088 \mathrm{bbl} / \mathrm{day} \text {, } \\
\text { Naptha: } 12,865 \mathrm{bbl} / \mathrm{day} \\
\text { LPG: } 2,048 \mathrm{bbl} / \mathrm{day} \\
\text { Processes with Secondary } \\
\text { Outputs: } \\
\text { Coal: } 216 \mathrm{MWe} \\
\text { HTGR: } \mathrm{O}_{2}-6,355 \\
\text { tons/day }\end{array}$ & $\begin{array}{l}0.16 \text { tons/ } \\
\text { bbl liquids }\end{array}$ & $\begin{array}{l}\text { 39,264 without carbon capture } \\
\text { (HTGR-integrated coal-to-liquids } \\
\text { using HTSE for } \mathrm{H}_{2} \text { production) } \\
\text { 8,012 with carbon capture }\end{array}$ \\
\hline $\begin{array}{l}\text { Natural Gas } \\
\text { to Methanol } \\
\text { to Gasoline }\end{array}$ & Gas & $\begin{array}{l}\text { Gasoline: 33,471 bbl/day } \\
\text { LPG: 5,279 bbl/day }\end{array}$ & $\begin{array}{l}0.09 \text { tons/ } \\
\text { bbl liquids }\end{array}$ & $\begin{array}{l}3,473 \\
\text { (HTGR-integrated natural gas-to- } \\
\text { methanol-to-gasoline with gas } \\
\text { recycle) }\end{array}$ \\
\hline $\begin{array}{l}\text { Coal to } \\
\text { Methanol to }\end{array}$ & Coal & $\begin{array}{l}\text { Gasoline: } 61,173 \text { bbl/day } \\
\text { LPG: 9,648 bbl/day }\end{array}$ & $\begin{array}{l}0.0013 \text { tons/ bbl } \\
\text { liquids }\end{array}$ & $\begin{array}{l}92 \\
\text { (HTGR-integrated natural gas-to- }\end{array}$ \\
\hline
\end{tabular}


Table 2. (continued).

\begin{tabular}{|c|c|c|c|c|}
\hline $\begin{array}{c}\text { Industrial } \\
\text { Areas }\end{array}$ & $\begin{array}{l}\text { Conventional } \\
\text { Process }\end{array}$ & $\begin{array}{c}\text { Main Products (from } \\
\text { conventional and HTGR- } \\
\text { integrated) }\end{array}$ & $\begin{array}{c}\mathrm{CO}_{2} \text { Emissions } \\
\text { Eliminated (per } \\
\text { unit product) }\end{array}$ & $\begin{array}{c}\text { Reduction in } \mathrm{CO}_{2} \text { Emissions }{ }^{1} \\
\text { (tons/day) }\end{array}$ \\
\hline \multirow[t]{2}{*}{ Gasoline } & \multirow{7}{*}{ Coal } & $\begin{array}{l}\text { Process with Secondary } \\
\text { Outputs: }\end{array}$ & & $\begin{array}{l}\text { methanol-to-gasoline using HTSE for } \\
\mathrm{H}_{2} \text { production) }\end{array}$ \\
\hline & & HTGR: $\mathrm{O}_{2}-7,358$ ton/day & \multirow{4}{*}{$\begin{array}{l}101 \\
\text { tons/MMSCFD } \\
\text { without carbon } \\
\text { capture }\end{array}$} & \multirow{4}{*}{$\begin{array}{l}\text { 5,052 without carbon capture } \\
\text { (HTGR-integrated coal-to-substitute } \\
\text { natural gas using HTSE for } \mathrm{H}_{2} \\
\text { production) }\end{array}$} \\
\hline \multirow{5}{*}{$\begin{array}{l}\text { Coal to } \\
\text { Substitute } \\
\text { Natural Gas }\end{array}$} & & Substitute natural gas: & & \\
\hline & & 50 MMSCFD & & \\
\hline & & $\begin{array}{l}\text { Process with Secondary } \\
\text { Outputs: }\end{array}$ & & \\
\hline & & \multirow{2}{*}{ HTGR: $\mathrm{O}_{2}-2,531$ tons/day } & 1.7 tons/ & 85 with carbon capture \\
\hline & & & $\begin{array}{l}\text { MMSCFD natural } \\
\text { gas with carbon } \\
\text { capture }\end{array}$ & $\begin{array}{l}\text { (HTGR-integrated coal-to-substitute } \\
\text { natural gas using HTSE for } \mathrm{H}_{2} \\
\text { production) }\end{array}$ \\
\hline \multirow{2}{*}{$\begin{array}{l}\text { Steam- } \\
\text { Assisted } \\
\text { Gravity } \\
\text { Drainage }\end{array}$} & \multirow[t]{2}{*}{ Methane } & \multirow[t]{2}{*}{ Bitumen: $49,000 \mathrm{bbl} / \mathrm{day}$} & 0.06 tons/ & 2,700 \\
\hline & & & bbl bitumen & $\begin{array}{l}\text { (HTGR-integrated steam-assisted } \\
\text { gravity drainage) }\end{array}$ \\
\hline 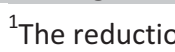 & . & n dioxide that was capt & & \\
\hline
\end{tabular}




\section{RECOMMENDATIONS}

Overall, the HTGR-integrated processes produce much lower carbon dioxide emissions than conventional processes. However, it is not practical to use results from this first phase of the study to make recommendations or draw conclusions regarding the best process. A detailed economic analysis is required to obtain an acceptable basis for ranking the processes. This study showed that the major advantage of a nuclear-integrated case is the potential for a significant reduction of carbon dioxide emissions. It is recommended that the study continue so the relative costs and economic merit associated with each of the processes can be evaluated.

Therefore, the next phase will focus on developing a detailed economic model based on the conventional and nuclear-integrated processes examined in Phase 1. The model will incorporate estimates of equipment size and operating costs, and potential economic impacts from climate change legislation. The output will include product pricing and evaluations of the impacts of climate change legislation and the effects of raw material costs on product costs. These results will help determine how conventional and nuclear-integrated processes compare economically.

As opportunities for HTGR integration are identified in the future, they will be evaluated based on the approach used in this study. 


\section{REFERENCES}

1. Nuclear Energy Institute, Nuclear Promoted as Climate Change Solution at UN Talks, http://www.nei.org/resourcesandstats/publicationsandmedia/insight/insightjanuary2009/nuclearpromoted-as-climate-change-solution-at-un-talks, January 2009.

2. Cook, J., 1985, "Nuclear Follies," Forbes, February 11, 1985.

3. World Nuclear Association, Nuclear Power in the U.S.A., http://www.worldnuclear.org/info/inf41.html, updated September 2009. 